The facts relating the side-chain constitution to the antirachitic properties of their irradiation product can be summarized thus :

\begin{tabular}{|c|c|c|c|}
\hline Sterol & $\begin{array}{l}\text { Carbon atoms } \\
\text { in side chain }\end{array}$ & $\begin{array}{l}\text { Double bond } \\
\text { in side chain }\end{array}$ & $\begin{array}{c}\text { Antirachitic } \\
\text { potency }\end{array}$ \\
\hline Dehydrocholesterol & 8 & 0 & +++ \\
\hline Ergosterol & 9 & 1 & \\
\hline Dihydroergosterol & 9 & 0 & ++1 \\
\hline Dehydrostigmasterol & 10 & 1 & $?$ \\
\hline $\begin{array}{l}\text { Dihydrodehydrostigma- } \\
\text { sterol (Dehydrosito- } \\
\text { sterol) }\end{array}$ & 10 & 0 & + \\
\hline
\end{tabular}

It has been suggested by Schoenheimer that the number of carbon atoms in the side-chain has a profound effect on the absorbability of sterols. If this be so, and if it apply also to the irradiation products, the explanation of the facts cited may be found along these lines. Difficulty in accepting such an explanation, however, arises from the fact that ergosterol shows, like sitosterol and other plant sterols, poor absorbability, while cholesterol is very well absorbed, yet the irradiation product of ergosterol is apparently absorbed as easily as that of dehydrocholesterol.

The various papers here summarized are supplemented in the same journal by a very interesting account, from Brockmann and Chen, of an antimony trichloride colour-test for both vitamin $D_{3}$ and calciferol. The authors claim a considerable degree of specificity for the test, and it will doubtless be eagerly tried by many workers in this field.

\section{A. L. Bacharach.}

\title{
British Regional Geology
}

$\mathrm{I}^{\mathrm{N}}$ the new Museum of the Geological Survey at South Kensington the exhibition of British geology has been arranged on the basis of a division of the country into eighteen districts, each of which forms a geological and geographical province of distinctive type. To each region a separate division of the main floor or first gallery has been assigned, and in order to render the exhibits more intelligible descriptive handbooks have been prepared to serve as guides. These handbooks, issued under the general title of "British Regional Geology", also serve as com. pendious summaries of local geology. Eleven have already been published and these are briefly noticed below.

The Survey is to be warmly congratulated on the success of this important new enterprise. Each handbook is beautifully illustrated with maps, diagrams and plates, and the descriptive matter adequately provides all the necessary detail for a general comprehension of the area concerned. The complete series will constitute the most authoritative and attractive account of British geology as a whole which has ever appeared; one, indeed, that will be indispensable to students for purposes of general study. The individual numbers, issued at the remarkably low price of $1 s$. $6 d$. each, serve as welcome introductions to the more specialized sheet memoirs, and also as guides to tourists and others who wish to appreciate the interest and significance of the geological features of any British district.

"London and Thames Valley" 1 embraces a region from Oxfordshire and north Wilts to Essex and north Kent. It thus comprises beds ranging in age from Lias to Pleistocene and Recent, the main features being the Chalk escarpment of the Chiltern Hills and its continuation west of the Goring Gap, and the middle of the London Basin. Palæozoic formations are known from numerous borings, most of the rocks bearing a general resemblance to those of the Welsh Borders. As in most of the other handbooks of the series, an excellent list of maps and memoirs and a selected bibliography of other publications dealing with the district are appended.

The handbook on "The Wealden District"' covers the area to the south of the above and is probably one of the most familiar geological regions in the world. The Weald proper is continued across the Straits of Dover into the Bas Boulonnais. Beds of many ages are concealed beneath the covering of surface rocks, and at the eastern end of the Weald every system of older stratified rocks from the Silurian upwards is represented, although the complete sequence recognized has not been found in any one boring. A very clear diagrammatic section is given showing the active collieries and working seams of the Kent Coalfield. Water, however, is fundamentally the most important of the economic resources of the Wealden District, since practically all that is used is derived from underground sources.

"Bristol and Gloucester District"3 extends from the Forest of Dean across the Severn to the Cotteswold and Mendip Hills. Geologically speaking, it is one of the most varied districts of Britain, for, with the exception of the Ordovician 
and possibly the Permian, there is exposed at the surface every geological formation from the Cambrian to the Cretaceous. Scenically, some of the most striking features, including caverns, gorges and bare rocky erags and uplands, are developed from the Carboniferous Limestone. On the west, limestones again dominate the scenery, the Inferior and Great Oolites forming the mural scarp of the Cotteswolds. These great limestone formations have attracted many famous geologists, the names of Arthur Vaughan and S. S. Buckman being pre-eminent as a result of their classic work on zoning. Tectonically, the synclinal areas of the Bristol, Somerset and Forest of Dean Coalfields and the echeloned periclines of the Mendips are of special interest.

"South-West England" is a region of high moorlands, including the Devonian rocks of Exmoor and the Quantocks, and the granite masses from Dartmoor to Land's End and the Scilly Isles. At the base of the geological sequence lie the PreCambrian rocks of the Lizard and Start Point. In 1834, De la Beche had already produced a geological map of Devon which led to his appointment as the first Director of the newly established Survey. Since then the region has been famous not only for the pioneer investigations of its mineral wealth, but also for the many contributions it has stimulated to our knowledge of petro. logy generally, culminating in the work of 'Teall, Flett, Dewey, and, still more recently, of Brammall and his school of co-workers. This handbook is itself a most valuable introduction to a great variety of petrological problems and there is, moreover, a most interesting section on mines and mining.

The handbook entitled "The Welsh Borderland"s covers a region from Shrewsbury to south of Monmouth. It includes such geologically classic areas as the Wrekin, the Longmynd and the Malverns, where some of the most ancient rocks of England and Wales appear boldly at the surface ; the Stiperstones and Shelve country and the Breidden Hills, where Ordovician rocks are magnificently displayed; and Wenlock Edge, famous in the sequence of the Silurian System which was first established by Murchison in $1835^{\circ}$ as a result of his work in the Welsh Borderland. Much of the modern research in the region was initiated by Lapworth and Watts, whose stimulating example has been vigorously followed by a host of colleagues and former students. Indeed, many geologists have received their field-training in this area, which is unrivalled for the great variety and interest of its formations, many of which, moreover, are highly fossiliferous. The present handbook provides an invaluable guide to the classes who annually visit Shropshire and the country about the Malverns for instruction in field-geology.

Another classical region in the history of geology is dealt with in "North Wales"6. Here Sedgwick set himself the task of disentangling the structure of the rugged mountain district of Snowdonia and Lleyn, and here he founded the Cambrian System. Since then North Wales has attracted to its study an ever-growing band of stratigraphers, palæontologists and petrologists. The region is essentially characterized by Lower Palæozoic rocks, display. ing one of the finest sequences of Cambrian, Ordovician and Silurian strata to be found in Europe ; showing by deep-seated erosion the cores of ancient volcanoes; and revealing in its crumpled, folded, cleaved and fractured sediments the record of several periods of major earthmovements. Of the remaining systems, the underlying Pre-Cambrian is well represented in Anglesey, while the Carboniferous and New Red Sandstone cover fairly extensive tracts on the borders. Like the foregoing, this handbook will be in great demand by students attending geological fieldcourses.

"The Pennines and Adjacent Areas"; include the Fell country from Stainmore Pass to the Craven district, consisting mainly of Carboniferous Limestone ; the Central Pennines between Skipton and the Peak, largely formed of the Millstone Grits (and shales); the Derbyshire Hills of Carboniferous Limestone; the Lancashire and North Staffordshire Coalfield on the west; and, on the east, the coalfield of York, Derby and Nottingham which, in potential resources, is the most important in Britain. The great diversity of geological and physical features is accompanied by an even greater variety of economic interest and by a corresponding inequality in the distribution of population. The oldest rocks in the region-apart from the supposed Pre-Cambrian of Ingleton-are the Lower Palæozoic formations exposed in the valleys below Ingleborough and in the Howgill Fells. The interest of the coalfields needs no stressing, but geologists will particularly appreciate the useful summary of the structure of the region and the excellent account of the Pleistocene glaciation.

Northumberland, Durham, the Lake District and the Isle of Man are dealt with in "Northern England"s. The Northern Pennines continue to the Border and separate a great coalfield on the east from the most attractive scenic area of England, an area which is itself fringed with coal and iron fields. The formations range from the Ordovician to the Jurassic and include a long history of igneous activity, the products of which are responsible for the rugged hills of Borrowdale; the worn-down volcano of the Cheviots; the 
well-known granites and Carrock Fell complex of the Lake District; the Great Whin Sill, surmounted for a considerable length of its outcrop by the Roman Wall; and a swarm of dykes which has been traced across Scotland to the Tertiary volcano of Mull. Along the Durham coast, the Magnesian Limestone of the Permian System constitutes one of the most puzzling formations-lithologically and structurally-to be found anywhere in the world. The results of much recent work in the Lake District have been incorporated in the handbook, but in a future revision more attention might be given to the North Pennine ore-deposits and to the Tertiary dykes, or at least to the desirability of including bibliographical references to these subjects of recent research.

"The South of Scotland"s is devoted to the region between the Cheviots and Solway Firth on one hand, and the faulted southern margin of the Midland Valley on the other. Here some of the fundamental principles of geology were established by Hutton and recorded in his "Theory of the Earth" (1795). It was in the Southern Uplands, too, that Lapworth began the far-reaching studies in which he demonstrated the value of graptolites as aids in working out the complicated succession and structure of a highly folded region. The area is mainly occupied by Ordovician and Silurian strata folded in part after the Arenig and, as a whole, at the close of the Silurian. The intrusions of serpentine and other plutonic rocks which have usually been regarded as pre-Glenkiln are considered by Dr. Pringle to be part of the PreCambrian floor on which the Arenig strata were deposited. Small areas of Old Red Sandstone, Carboniferous and New Red Sandstone occur, with abundant illustrations of igneous activity in the great granite complexes of Galloway and the volcanic rocks and necks of Lower Carboniferous age. This handbook, like the one that follows, has a selected bibliography after each section, in some respects a preferable arrangement to placing the whole at the end. The map of the region, showing many localities of geological interest not easily found on detailed maps, is particularly clear.

"The Grampian Highlands"10 embraces the region between the Highland Boundary Fault and the Great Glen Fault. It excludes Arran, but is extended to take in Colonsay. The two fault lines represent great dislocations along which movements are still taking place, as witnessed by the earthquakes which occur about Inverness and Comrie. The district includes the highest ground in Britain and is geologically by far the most difficult on account of the inexplicable complexity of its structure. The most important formations are those of the Moine and Dalradian divisions of the Highland Schists. A particularly valuable feature of the handbook is the clear summary which it contains of the different interpretations of succession and structure which have been proposed; this is the more useful because, as the author says, "it will doubtless appear to the reader that there are as many opinions as observers". The treatment of the igneous rocks earlier than, or associated with, the Dalradian metamorphism, and that of the Newer, or Caledonian, intrusions is also worthy of special praise. All students of tectonics and petrology will find this handbook a most helpful guide to a region of tantalizing perplexity.

Under the title "Scotland: The Tertiary Volcanic Districts"11 the magnificent record now exposed in the west of Scotland, of the intense and prolonged igneous activity which broke out in Early Tertiary times, is discussed. The vast amount of denudation which has since taken place has revealed the extensive roots of mighty volcanoes and the deeper-seated plutonic rocks that crystallized beneath the covering of lavas. The complexity of the vents and intrusions and the orderliness of the ring-structures (ring-dykes and cone-sheets) are unsurpassed in any other part of the world. Only brief accounts of the pre-Mesozoic formations are given, the bulk of the handbook being devoted, as its title indicates, to $(a)$ the plateau lavas; $(b)$ the Central Intrusion complexes of Mull, Ardnamurchan, Skye, Rum, St. Kilda and Arran ; and (c) the dyke-swarms. This justly famous petrographic province has stimulated world-wide discussion of problems of petrogenesis. In this connexion it may be pointed out that the official interpretation of the upward passage of gabbro into granophyne in the ring-dykes of Mull as the result of gravitational differentiation in situ has not remained unchallenged. The handbook is lavishly illustrated and, at least for petrologists, it may be hailed as the most attractive example of a series that is a worthy commemoration of a hundred years of geological research in Britain.

\footnotetext{
1 "London and Thames Valley." By R. L. Sherlock. Pp. $70+5$ plates.

2"The Wealden District." By F. H. Edmunds. Pp. $85+13$ plates. a "Bristol and Gloucester District." By F. B. A. Welch and R. Crookall. Pp. $86+12$ plates.

" "South-West England". By H. Dewey. Pp. $75+12$ plates.

s"The Welsh Borderland." By R. W. Pocock and T. H. Whitehead. Pp. $81+11$ plates.

B "North Wales." By B. Smith and T. N. George. Pp. $92+12$ plates.

7"The Pennines and Adjacent Areas." By D. A. Wray. Pp. $87+11$ plates.

8 "Northern England." By T. Eastwood. Pp. $76+8$ plates

- "The South of Scotland." By J. Pringle. Pp. $97+7$ plates.

10 "The Grampian Highlands." By H. H. Read. Pp. $81+10$ plates.

11 "Scotland: The Tertiary Volcanic Districts." By J. E. Richey. Pp. $115+9$ plates.

London: H.M. Stationery Office. $1 s, 6 d$. net each.
} 